\title{
The Influence of Blended Learning-Based English Learning Model on Students Activities and Learning Outcomes in University
}

\author{
Yosi Marita ${ }^{*}$ and Elva Utami
}

Prof Dr Hazairin SH University, Bengkulu, Indonesia

*Corresponding author. Email: yosi@unihaz.ac.id

\begin{abstract}
Rapid technological advances have an impact on the world of education, especially in learning. One of them is the blended learning-based learning model, which has now become part of efforts to improve university quality. This examination aims to investigate the distinctions in learning results between understudies utilizing the blended learning model and understudies utilizing the expository learning technique. In this examination, the technique utilized was the experimental method. This research was conducted at the Economic Study Program of UNIHAZ Bengkulu. Experimental and control group design was employed and 25 students were classified into these groups. Pre-test and post-test were given to each group of students. The T-Test was utilized to analyze the quantitative data. In light of the examination results, there are significant understudy learning results of the understudies treated utilizing a blended learning model contrasted with those treated utilizing the expository model. Thus, it very well may be presumed that the mixed learning strategy is able to be applied in the teaching cycle.
\end{abstract}

Keywords: Blended learning model, Expository learning, Learning outcomes.

\section{INTRODUCTION}

The development of education, technologies, and teaching method create new opportunities from the modernization of academic classes. Many studies on the application of new teaching models indicate that they are both more effective and efficient. In this research, an attempt was made to decide the influence of blended learning on economic understudies learning outcomes attending an English course [1][2]. Blended learning refers to two aspects, namely face-to-face and online learning. Blended learning aims to provide opportunities for students to learn independently, sustainably, and develop throughout life.

Blended learning is a mix of educating utilizing media innovation, virtual class, CD ROM, video realtime, and electronic mail [3]. The entirety of this joined with conventional types of classroom and one-on-one learning. The feeling of an end to be drawn that mixed learning consolidates web-based learning with conventional media as face-to-face learning. The advantages of mixed learning [4] are improving the learning outcomes, reducing the cost of learning, increase the ease of learning. Mixed learning may upgrade learning at the limit between the homeroom and the online situation. The understudy may step forward in their learning cycle when their virtual world is associated with this present reality. This possible advance forward is by all accounts identified with the zone of proximal improvement as in limit object, here mixed learning didactics may have the space of conveying the potential of the learning [5].

Blended learning appears to given the ideal mix, take in a cycle of both on the web and traditional learning. This mix may need a more perplexing perspective concerning the results of understudies' assessment and appraisal [6]. The mix chose should both have the option to address the issue of the understudies simultaneously and challenge the understudy to push ahead in English learning. There were various approaches to education in mixed guidance. A few courses have more online concentration than others and might be appropriate for distance learning. Others have the study hall and conventional learning mixed in. Blended learning is the two models characterized as an instructional program in which an understudy halfway learns through the online conveyance of learning and substance, with some 
component of understudy command after some time and spot.

The best utilization of mixed adapting adequately incorporates all understudy encounters to accomplish instructional objectives, instead of enhancing old models of guidance with new advances [7]. A teacher ought to support the understudies cooperate and pick significant and testing tasks. The assignment can be completed both conventional and web-based given a definitive mix to advance learning [8]. The speakers assume the significant part of facilitator and establish the climate were coordinated and guided learning an occur and assume this part in the web-based learning. It should then likewise be given master information through an instructor and further on be urged to collective work, the sharing of results, and the presentation of the last assignment.

From some experts' opinions, it very well may be reasoned that mixed learning is a model of learning that incorporates two aspects, consisting of traditional and web-based learning. With its existence, it is hoped that two aspects of information can be obtained from various sources. The motivation behind this investigation is to decide the learning outcomes also limitations during learning with the blended learning method, as well as how the effect of English learning based on blended learning.

Furthermore, it is crucial to mix the two strategies to make a more successful learning measure [9]. The online stage extends learning materials and improves openness for students as help to customary homeroom guidance [10]. This is a favorable position in language instructing, as the understudies are presented to shifted learning helps (recorded drills, discussion practice) which all add to expanding their insight. In conventional learning, students rely upon the material given by the teacher, which may not be adequate for their acquisition of language. This insufficiency is tended to through mixed learning, as understudies have expanded admittance to their training materials.

Conventional communication upgrades web-based learning by establishing a climate that upholds collaboration and improves talking abilities in the objective language [11]. The fundamental focus on language learning is to be furnished with the target language expertise that helps the student address genuine circumstances [12]. Cooperation in the homeroom setting is related to bunch uphold for critical thinking abilities [13]. This implies the student will have the option to deal with an undertaking as a group and accordingly figure out how to expand their intellectual capacities in critical thinking. Besides, the innovation interceded stage improves the English education.

From certain opinions of specialists, it tends to be reasoned that blended learning is viable in expanding information sources and results. This implies that understudies have an assorted hotspot for their materials, prompting a piece of expanded information.

\section{RESEARCH METHODOLOGY}

The quasi-experimental method was used as a method of this investigation. A pretest-posttest design was selected as the study design [14]. There were 25 understudies of the first semester at Economic Study Program UNIHAZ Bengkulu scholarly year 2019/2020 as the population in this study. This observation additionally raises the consciousness of the teacher's job and expanded the comprehension of a portion of the understudies' encounters. The double part of the teacher and an analyst likewise requested affectability and affirmation to guarantee an open observation [15].

Those 25 understudies were gathered in the experimental and control group. Prior to the lesson, the understudies took a test as a pre-test and do a treatement. In the experimental group, they were instructed by utilizing a mixed learning model. Besides, in the control group, the understudies were educated by utilizing the interpretive learning model. Toward the finish of the lesson, the understudies have to take a posttest.

The quantitative information acquired from the understudies' grades were investigated utilizing a descriptive statistical analysis and T-Test through SPSS. A few rules are crucial to prevail in a subjective meeting [16]. The perception of the learning cycle commonly affected English learning. It additionally helped in planning inquiries in the manner in which they did.

\section{RESULTS AND FINDINGS}

The descriptive statistics result of the students' scores analysis is displayed in Table 1.

Table 1. The minimum and maximum scores in the experiment and control class

\begin{tabular}{|c|c|c|c|c|}
\hline \multirow{2}{*}{ Description } & \multicolumn{2}{|c|}{ Control Class } & \multicolumn{2}{c|}{$\begin{array}{c}\text { Experimental } \\
\text { Class }\end{array}$} \\
\cline { 2 - 5 } & $\begin{array}{c}\text { Pre- } \\
\text { Test }\end{array}$ & $\begin{array}{c}\text { Post } \\
\text { Test }\end{array}$ & $\begin{array}{c}\text { Pre- } \\
\text { Test }\end{array}$ & $\begin{array}{c}\text { Post } \\
\text { Test }\end{array}$ \\
\hline Min. Score & 52 & 76 & 68 & 87 \\
\hline Max.Score & 73 & 78 & 78 & 90 \\
\hline $\begin{array}{c}\text { Average } \\
\text { Score }\end{array}$ & 62,5 & 77 & 73 & 88,5 \\
\hline
\end{tabular}

Based on the information listed in table 1, it can be seen that first, the minimum score in the pre-test of the control class was 52, while it was increased to 76 in the post-test of the control class. Meanwhile, The minimum student score in the pre-test of the experiment class was 73; it was increased to 78 in the post-test. Meanwhile, 
the students' maximum score of the experimental class's pre-test was 78; it increased to 90 in the post-test.

In light of the T-test examination, it was gained that the value of $t_{\text {hit }}=3.09$ and the $t$ value is $T_{t a b}-1.546$. The two values are then compared, and the result is that the count is bigger $(3.09>1.546)$. This means that the hypothesis is accepted. It implies that there is a huge impact on the utilization of blended learning on economic students' learning outcomes.

Moreover, based on the observation of the learning activities, the obtained data is displayed in Table 2 .

Table 2. Students' interaction in the learning activities

\begin{tabular}{|l|c|}
\hline \multicolumn{1}{|c|}{ Indicator } & Percentage \\
\hline Showing enthusiasm for learning & $80 \%$ \\
\hline Being nice to try the exercises given & $5 \%$ \\
\hline Being diligent in doing the task & $5 \%$ \\
\hline Being diligent and energetic & $10 \%$ \\
\hline
\end{tabular}

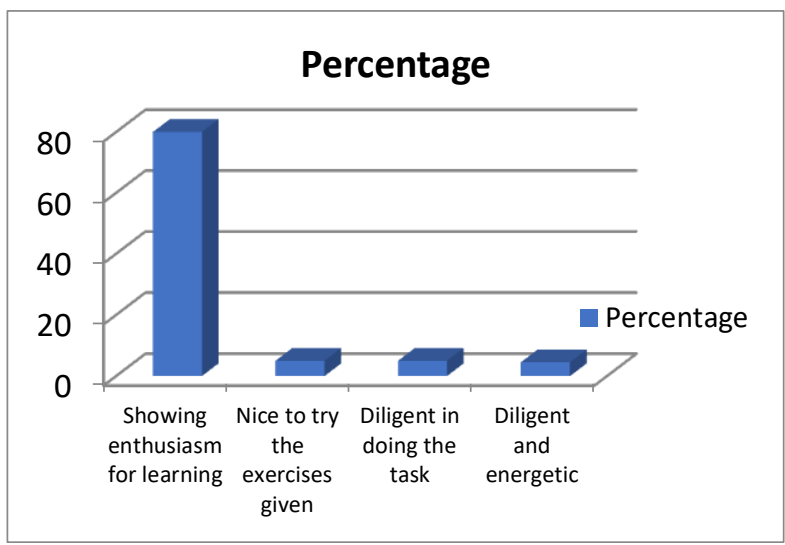

Figure 1 Students' interaction in the learning activities.

Based on the finding and results in this observation (Figure 1), the highest score on the students' interaction in learning activities are: showing enthusiasm for learning (80\%). The finding indicates that most understudies like to utilize online learning, both as a strategy to expand their English abilities and as a chance to generate interest and inspiration. The second highest for being diligent and energetic (10\%). Most students also feel interesting, easy, and good way to learn. The understudies remarked that it assisted them with learning new vocabulary notwithstanding being a variety of how to learn English materials. The third point is being nice to try the exercises given $(5 \%)$ and being diligent in doing the task $(5 \%)$.

The data gained from the observation showed that the students were more motivated to learn in the experimental class through the blended learning model. It because understudies got a larger number of materials other than those introduced by the educator in the homeroom. The online test can test learner knowledge more efficiently, and they even allow for multiple attempts if a learner wants to drill themselves into the information.

\section{DISCUSSION}

\subsection{Showing Enthusiasm for Learning}

The findings showed that enthusiasm has several meaning such as feeling or emotion and achieving. The factors influencing students' enthusiasm in English lessons were the instructional materials used by the lecturer and classroom environment. Most students showed that their level of interest is higher when they had a chance to watch a picture and video because they saw the language in use. The use of video in English lessons is given effective activities if the teacher used it appropriately. Furthermore, a video has motion: moving images have an obvious advantage over still visual in portraying concepts and processes in which motion is essential to learn.

There was an indicator of enthusiasm related to the students' behaviors in the class activity. That was the students are attending the lecture and other situational elements when attention was required. Understudies fit them around their current duties and responsibilities, drawn in with media substance and learning materials at whatever time was generally helpful to them. Besides, they did not need to make a trip anyplace to contemplate, they essentially sign in to the mixed gaining from the solace of their home. Web-based learning was effectively open on a lot more modest financial plans. Notwithstanding the accommodation and the expense, countless understudies are going to web-based learning courses since they have improved as an approach to learn. Those understudies who are not kidding about improving their agreement, mastering new abilities, and acquiring important capabilities were quick to take a crack at the best kind.

Inside a web-based conversation, each understudy reacts to the material of the learning (talks and books of the course) and remarks from different understudies. Understudies generally react to those subjects inside the more extensive discussion that most plainly address their individual concerns. This circumstance brings about more modest educating and learning occurred all the while inside the blended learning. While understudies read the entirety of their colleagues' commitments, they effectively participate in just those pieces of the discourse generally pertinent to their own advantages. Thusly, understudies controlled their own learning experience and the class conversations to meet some particular necessities. Preferably, understudies make their own person to the study while simultaneously removing a novel blend of applicable data. 
It implies that the understudies built their own studying and comprehension. The instructor just gave an animating climate. Blended learning which blends two methods of study: conventional and internet learning gives the instructors different techniques and methodologies in educating. The understudies had their styles and approaches in learning. They came from various foundations and language learning styles. This sort of distinction once in a while did not settle in the on-location class exercises. Then again, online exercises are given more individualized exercises. Utilizing the mixed student, the teacher chose different intelligent exercises that urge the understudies to develop their adapting separately, simultaneously, and cooperatively in blended learning.

\subsection{Being Nice to Try the Exercise Given}

This stage began with the instructor disclosing to the understudies the expectation of the activity. Students learned how to asked questions, how to negotiated meaning, and how to try to exercises given. They had the option to know various ways to deal with critical thinking just as to attempt the activities. It would like to include an introduction or review of grammatical concepts the students needed to accomplish the assigned exercise.

Exercise in a classroom activity that involved learners with the help of the lecturer in comprehending, manipulating, producing, and interacting in the target language with a communicative. When students did for the task, they should examine exhaust to ensure that they did not commit reckless errors. An undertaking that was truly significant gave more opportunity to finish assignments that were simpler or less significant. For instance, additional time ought to be put aside to peruse be a long section in English investigations than to deal with some short issue in English material. When perusing the investigations part, additional time ought to be spent on ideas that were more enthusiastically to comprehend.

\subsection{Being Diligent in doing the Task}

The task presented the subject and gave the understudies clear guidelines on what they needed to do at the assignment stage and may assist the understudies with reviewing some language that might be valuable for the undertaking. The primary undertaking stage included playing a chronicle. This gave the understudies an away from what will be anticipated from them. The understudies took notes and invested in energy planning for the undertaking.

Understudies in English classes learned English with understanding and habituation. A goal was accepted by almost every student in the current do the task of grammatical skill in English the classroom. Then it was important to examine English tasks for understanding to analyze. Students shared the responsibility for thinking and doing. They distribute their activity so that they understand and select answers based on these tasks given.

Their points were other is thought and beliefs, students must be explicit in belief or evidence and they must share the students decided where, when, and how to run their task. They discussed translation, English General: how to translate a text and sentences. They decided to answers and translate the text based on their knowledge. A large portion of the reactions focused on how they would have utilized various apparatuses, or they would have relegated at any rate one virtual task each week. These reactions are significant. Nonetheless, not many of the remarks focused on assignments given in the virtual study room. Inside an online conversation structure in mixed learning, the student may ponder remarks from others prior to reacting or proceeding onward to the following thing. This design permits understudies time to express reactions with significantly more profundity and thinking ahead than in a conventional conversation circumstance where the member should dissect the remark of another on the spot and detail a reaction or in any case lose the opportunity to add to the conversation. In giving errands, the focal point of the learning cycle moves to the actual understudies and permits them to go to the acknowledgment that the undertaking was a device to handle and tackle issues.

\subsection{Being Diligent and Energetic}

The web-based configuration permitted a powerful collaboration between the teacher and understudies and among the actual understudies. Assets and thoughts were shared, and consistent cooperative energy will be created through the learning cycle. Every individual added to the course conversations and remarks crafted by others. The energy that exists in the understudy focused Virtual Classroom was quite possibly the most special and essential characteristics that the mixed learning design has.

Students use the knowledge used in relation to the assignment to explain what they are doing. They were able to do the task meaningfully about the questions and order of, even though they did not use technical terms to do so, that is a set of procedures for finding the answer. Clearly, students' understanding comes into lecturer this lesson. It is the goal of helping students see what English lesson to develop students understanding in doing the task. It was an indication that understudies need to do a lot more exercises including various groups. In ensuing exercises, understudies were tested with deciphering issues in an assignment. Students did their task by using the grammatical and translation method. Students used their knowledge to make answers to the task. Students spent a great deal of time discussing alternative strategies 
with each other, in group discussion and as a whole class and giving the solution to problems. The important answers in the English task were developed by students for solving solutions. The errand gave backings the utilization of intuitive learning conditions as adding to self-bearing and basic reasoning. The analyst has made extraordinary walks in applying these ideas to their onground instructing.

In another view, a mixed learning technique for schooling can be an exceptionally viable elective mode of instruction for the developed, self-trained understudy, it is an improper learning climate for more reliant students. Web-based learning gives understudies command over their learning experience and considers adaptability.

Improving understudy's inspiration in contemplating the English is fundamental for educators. Understudies must felt agreeable and pleasant in homeroom. The finding of this paper indicated that the teacher could utilize blended learning in English courses. Utilizing blended learning could assemble the understudies' inspiration in the homeroom. The speaker could show utilizing the reading material and innovative gadget. It implies that other than the speaker clarifies the material utilizing the course reading, interpretation, and linguistic. They could join by utilizing innovation gadgets, for example, cell phones. Most understudies utilized cell phones in a day by day life. Utilizing it, the educator utilized it in the instructing learning measure. The speaker requested the understudies to utilize one from the applications in the cell phone such as WhatsApp, etc. Utilizing this application, the teacher could know the nature of the English investigation of understudies, and the speaker assisted the understudies with expanding in English subject material. Most understudies imagine that learning English is troublesome in light of the fact that they should know the material in instructing and studying.

\section{CONCLUSION}

It tends to be inferred that first understudies performed fundamentally distinctively after they were dealt with utilizing the blended model from those treated utilizing the informative model. It very well may be seen from the understudies' greatest score of the test class' pre-test was 78; it expanded to 90 in the post-test. Furthermore, coordinating on the web conversation and learning exercises with up close and personal class exercises in English upgrades understudies' inspirations on English learning. Web-based learning may well offer understudies an opportunity to build up their language capacities. The utilization of chatting groups and online conversations in mixed learning may likewise have dynamic action and along these lines open up for additional understudies to examine outside. Blended learning happens in a virtual environment and appears to goodly affect the improvement of the understudies' skills. It relies completely upon the instructor's capacity to draw in and make revenue and comprehend English learning. Above all, mixed learning brings a bigger pool of learning assets and materials, instruments that are valuable in information extension, and innovation or framework quality that will influence effectiveness, dependability, and ease. Along these lines, mixed learning is seen to be an instructional procedure that is embraced in language educating, to create the best information securing and language facility between the understudies.

Most understudies believe that English learning is troublesome in light of the fact that they should know the vocabulary, meaning, grammar, etc. The teacher should have the option to lose the worldview for understudies, and they should give the educating learning measure are open and valuable for understudies. Mixed learning was appropriate in the educating and learning measure since it could improve the learning admittance to materials and learning exercises, and it could support and upgrade the job of the educators, the encounters of the understudies, and the social climate. Also, it could improve the understudies' inspiration in considering the English language, because the mixed learning model offers different and energizing learning exercises utilizing the web and other innovation in instruction.

\section{REFERENCES}

[1] Dwiyogo, Warsis D. Pembelajaran Berbasis Blended Learning. Depok: PT Raja GrafindoPersada 2018

[2] Anggitasari, M., Tarwana, W., Febriani, R. B., \& Syafryadin, S. Using Wattpad to Promote the Students' Responses to Literary Works: EFL College Students' Perspectives and Experiences of Enjoying Short Stories. Jadila: Journal of Development and Innovation in Language and Literature Education, 1(2), 2020, 182-192.

[3] Thorn, K. Blended learning: how to integrate online and traditional learning. London: Kogan Page. 2003

[4] Yendri, D. Blended learning: model pembelajaan kombinasi e-learning dalam pendidikan jarak jauh. Universitas Andalas. 2011. Diakses melalui:http://fti.unand.ac.id/images/BlendedLearni ng.pdf.t tanggal 22 Oktober 2020.

[5] Ja'ashan, M.M. Perception and attitudes toward Blended Learning for English Course: A Case Study of Students at University of Bisha. English Language Teaching, $2015 . \quad 8(9), 40-$ 50.doi:10.5539/elt.v89pn40. 
[6] Ghazzizadeh, T., The Effect Blended Learning on EFL Learners' Reading Profiecy. Journal of language Teaching and Research, 8(3),606614.doi:10:1750/jltr.0803.21.

[7] Zhang, W. Comparing Learning Outcomes Blended Learning and Traditional Face to Face Learning of University Students in ESL Courses. International Journal on E-Learning, 17(2), 2018. 251-273.

[8] Picciano, A.G., Dziuban, C. Blended Learning Research Perspective. New York, NY: Routledge Publication.

[9] Adas, D. Writing Difficulties and New Solution: Blended Learning as An Approach to Improve Writing Abilities. International Journal of Humanities and Social Science, 2013, 3(9), 254266.

[10] Yoon, S.Y. The Perspective and Effectiveness of Blended Learning in L2 Writing Korean University Students, Multimedia Assisted Language Learning, 2010, 13 (2), 177-204.

[11] Bandtvlai, C. Enhancing Students' Language Skill through Blended Learning. Electronic Journal of eLearning, 2016, 14(3)220-229.
[12] Marsh, D. Blended Learning: Creating Learning Opportunities for Language Learner. New York, NY: Routledge Publication. 2012.

[13] Senffner, D. Blended Learning That Works. Alexandria, VA. Assosiaciation for Talent Development. 2015.

[14] Rhem,. J. Blended Learning Across the Disciplines, across the Academi. Sterling, VI: Stylus Publishing, LLC. 2012.

[15] Emzir. Metodologi penelitian pendidikan kuantitatif \& kualitatif. Jakarta: Rajawali Pers. 2012.

[16] Shih. R. C. Blended Learning Using Video Based. Blogs; Public speaking for English as a Second Language Student. Australasian Journal on Educational Technology, 2010. 26(6).883897 .doi:http: //doi.org/10.14742. 